\title{
Tedavisiz üç yıllık takiplerinde belirgin progresyon göstermeyen taşlı yüzük hücreli mide kanseri olgusu
}

\author{
A case of signet ring cell gastric cancer showing no progression without treatment for a period of \\ three years
}

Kamil ÖZDIL ${ }^{1}$, Abdurrahman SAHIN $^{1}$, Resul KAHRAMAN ${ }^{1}$, Hakan DEMIRDAĞ ${ }^{1}$, Turan ÇALHAN ${ }^{1}$, Bilgehan YÜZBAŞIOĞLU' Suat KILIÇ르, Hakan KARABULUT ${ }^{3}$, H. Mehmet SÖKMEN ${ }^{1}$

Ümraniye Eğitim ve Araştırma Hastanesi, Gastroenterolji Kliniğíi, Genel Cerrahi Kliniği², Patoloji Kliniğí3, Istanbul

Mide kanseri, dünyada mortaliteye neden olan en slk ikinci kanserdir. Taşl yüzük hücreli mide kanserinin genel olarak kötü prognoza sahip olduğu bildirilmektedir. Bu vaka sunumunda 3 yıllık takibe rağmen çok hızlı progresyon göstermeyen taşlı yüzük hücreli mide kanseri sunulmuștur. Hastanın cerrahi tedaviyi kabul etmemesi nedeniyle üç yıl süreyle takip edilmesi mümkün olmuştur. Bu olguda radyolojik ve endoskopik incelemelerde üç yılllk takibe reğmen yayılım veya tümör çapında belirgin artış saptanmamıștır

Anahtar kelimeler: Taşl yüzük hücreli mide karsinomu, prognoz

\section{GİRISS}

Mide kanseri, dünyada mortaliteye neden olan en sık ikinci kanserdir. Taşlı yüzük hücreli mide kanserinin genel olarak kötü prognoza sahip olduğu bildirilmektedir. Bu vaka sunumunda 3 yıllık takibe rağmen çok hızlı progresyon göstermeyen taşlı yüzük hücreli mide kanseri sunulmuştur. Hastanın cerrahi tedaviyi kabul etmemesi nedeniyle üç yıl süreyle takip edilmesi mümkün olmuştur.

\section{OLGU SUNUMU}

Altmışbir yaşında bayan hasta mide ağrısı yakınmasıyla gastroenteroloji polikliniğine başvurmuş. Fizik muayenesinde epigastrium hassasiyeti dışında patoloji saptanmamış. 2006 yılında dış merkezde mide ağrısı nedeniyle yapılan endoskopisinde mide insisura angularis bölgesinde 8-10 mm boyutlu ülser saptanmış, ülser ve çevresinden alınan biyopsilerde taşlı yüzük hücreli karsinom saptanmış. Hastaya operasyon önerilmiş ancak hasta ameliyat olmayı kabul etmemiş. Aralıklı olarak proton pompa inhibitörü ilaç kullanmış. Üç yıl sonra mide ağrısının devam ettiğini belirterek polikliniğimize başvuran hastaya kontrol üst gastrointestinal sistem endoskopisi yapıldi. Yine insisura angularis bölgesinde 10-12 mm boyutlu yüzeyi hafif irregüler görünümde beyaz eksudayla kaplı mukoza düzeyinde ülser görüldü. Ülser ve çevresinden biyopsiler alındı. Biyopsilerin patolojik incelemesinde taşlı yüzük hücreli
Gastric cancer is the second most common cause of mortality after lung cancer worldwide. Gastric cancer with the histological diagnosis of signet ring cell carcinoma is generally considered to have a poor prognosis. We present a patient diagnosed with early-stage signet ring cell gastric carcinoma three years ago who refused surgical treatment. The disease showed no marked progression endoscopically or radiologically during the follow-up period of three years. Histopathological diagnosis of signet ring cell gastric carcinoma should not be considered as an absolute indicator of poor prognosis.

Key words: Signet ring cell gastric carcinoma, prognosis, untreated

karsinom saptandı. Preoparatif değerlendirme amacıyla yapılan toraks ve batın bilgisayarlı tomografi (BT) incelemelerinde herhangi bir metastaz veya komşu organ yayllımı saptanmadı. TNM sistemine göre T2 NO M0 olarak kabul edildi. Hastaya operasyon önerildi ancak yine ameliyat olmayı kabul etmedi.

Endoskopik biyopsi materyalinin histolojik incelemesinde uniform, diffuz şekilde infiltre, hiperkromatik ve eksantirik

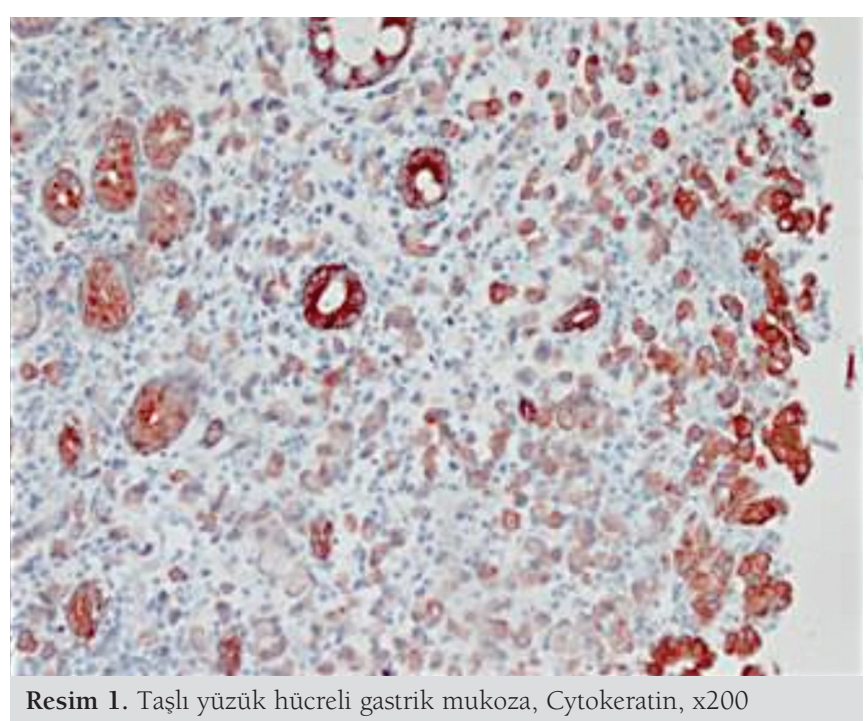
Tel: + 902166321818 • Faks: + 902169327124 E-mail: kamilozdil@gmail.com Gelis Tarihi: 07.01.2011 Kabul Tarihi: 26.02.2011 


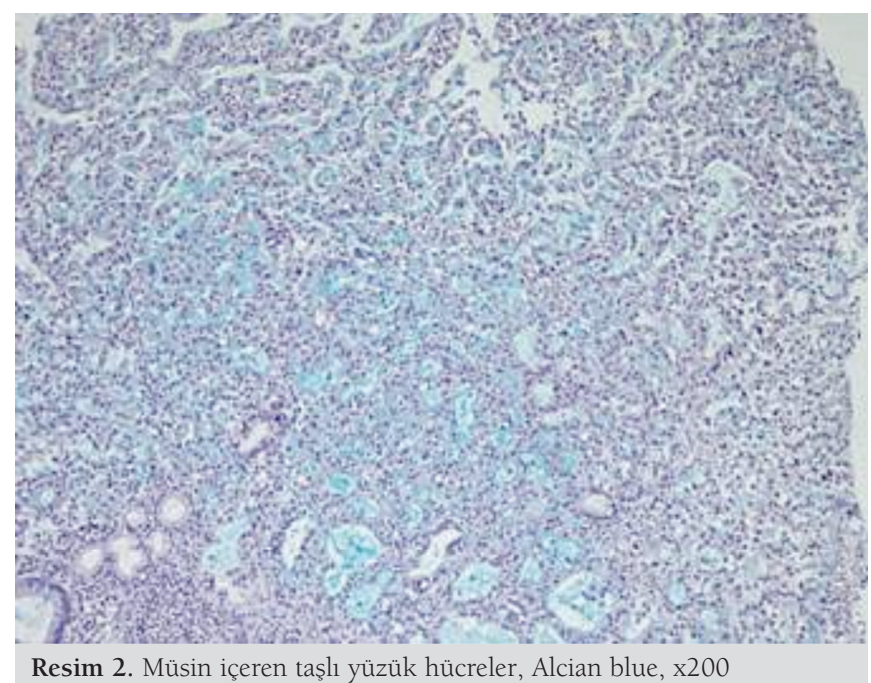

yerleşimli nükleuslara sahip müsin içeren içeren (taşlı yüzük hücreli), gastrik mukoza saptandı. Immunohistokimyasal (cytokeratin) ve histokimyasal (PAS ve Alcian blue) incelemelerinde malign görünümlü hücrelerin müsin içerikleri ve tanı teyid edildi.

\section{TARTIŞMA}

Mide kanseri dünya çapında mortaliteye neden olan kanserler arasında ikinci sıklıkta görülmektedir (1). Amerika Birleşik
Devletleri'nde mide kanseri tanılı erkek hastalarda 5 ylllık yaşam beklentisi \%18.6, kadınlarda \%25.2'dir (2). Taşlı yüzük hücreli mide kanserleri diğer histolojik tiplere göre daha kötü prognoza sahip olarak bildirilmektedir $(3,4)$. Bununla birlikte son yıllarda yapilan çalışmalarda histolojik olarak taşlı yüzük hücreli karsinom tanısının diğer histolojik tiplerle karşılaştırıldığında bağımsız bir risk faktörü olmadığı bildirilmiştir (5-7).

Taşlı yüzük hücreli kanser tanısı konulan hastaların prognozunun orta ve yüksek derecede diferansiye gastrik kanserlere benzer olduğuna dair yayınlar mevcuttur. Bu durum özellikle erken evredeki kanserler için daha belirgindir. Evre I-III kanserlerde histolojik subgruplarla prognoz arasındaki ilişki istatistiksel olarak anlamsız bulunmuştur (8).

Mide kanseri tanısı konulan ve opere olmaya uygun hastalar genel olarak ameliyat edilmekte olduğundan erken evrede tespit edilen hastanın takibi mümkün olmamaktadır. Bu şekilde takip edilebilen vaka sayısı sınırlı sayıdadır. Bu vakada hastanın israrla operasyonu kabul etmemesi nedeniyle erken evredeki taşlı yüzük hücreli mide kanserini takip etmek mümkün olmuştur. Üç ylllık takiplerinde belirgin progresyon saptanmayan, BT'de uzak metastaz veya komşu organ yayllımı saptanmayan hasta, literatürde geçen ve erken evredeki taşlı yüzük hücreli kanserlerin de diğer histolojik subtiplere benzer seyir gösterdiğine dair sonuçlara (8) benzer bulunarak, takdim edilmiştir.

\section{KAYNAKLAR}

1. Neuguet AI, Hayek M, Howe G. Epidemiology of gastric cancer. Semin Oncol 1996; 23: 281-91.

2. Houghton JM, Wang TC. Tumors of the stomach. In: Feldman M, Friedman L, Brandt L, Gastrointestinal and Liver Disease. $8^{\text {th }}$ edition. Sanfrancisco; Saunders Elsevier, 2006; 1139-61.

3. Yokota T, Kunii Y, Teshima S, et al. Signet ring cell carcinoma of the stomach: a cilinicopathological comparison with the other histological types. Tohoku J Exp Med 1998; 186: 121-30.

4. Theuer CP, Nastanski F, Brewster WR, et al. Signet ring cell histology is associated with unique clinical features but does not affect gastric cancer survival. Am Surg 1999; 65: 915-21.

5. Kim DY, Park YK, Joo JK, et al. Clinocopathological characteristic of signet ring cell carcinoma of the stomach. ANZ J Surg 2004; 74: 1060-4.

6. Li C, Kim S, Lai JF, et al. Advanced gastric carcinoma with signet ring cell histology. Oncology 2007; 72: 64-8

7. Lazar D, Taban S, Sporea I, et al. Gastric cancer: correlation between cilinicopathological factors and survival of patients. II. Rom J Morphol Embryol 2009; 50: 185-94.

8. Park JM, Jang YJ, Kim JH, et al. Gastric cancer histology: Clinicopathologic charateristics and prognostic value. J Surg Oncol 2008; 98: 520-5. 